\title{
Системні підходи до формування мотивацій до здорового способу життя, занять фізичною культурою та використання оздоровчого харчування в осіб, які займаються фітнесом
}

\section{Я. В. Першегуба} Національний університет фізичного виховання і спорту України,
Київ, Україна

\begin{abstract}
Резюме. Показано, что формирование мотивации к оздоровительному питанию в фитнесе нужно проводить системно с использованием методов рейтинговой оценки действенности формирования мотивации. Разработаны концептуальные подходы к формированию мотивации у лиц, которые занимаются фитнесом, к здоровому образу жизни, занятиям физической культурой и использованию оздоровительного питания. Показано, что у мужчин и женщин разные мотивы формирования положительной мотивации.

Ключевые слова: фитнес, мотивация, здоровый образ жизни, занятия физической культурой, оздоровительное питание.
\end{abstract}

Summary. Problems of formation of motivation in individuals who are engaged in fitness to a healthy way of life, to employment физическою by culture and uses of an improving food are considered. It is noticed, that motivation formations to an improving food in fitness need to be spent it is system with use of methods of a rating estimation of effectiveness of formation of motivation. Conceptual approaches to formation of motivation at individuals who are engaged in fitness to a healthy way of life, to employment by physical training and uses of an improving food are developed. It is shown, that at men and women different motives of formation of positive motivation.

Key words: fitness, the motivation, a healthy way of life, employment by physical training, an improving food.

Постановка проблеми. Проблема формування мотивації $\epsilon$ одним із основних напрямів психологічних досліджень, який активно розробляється. Загальні питання фрормування мотивації досліджуються в межах різних парадигмальних підходів психології, а також в роботах з соціології, психофрізіології, медицини, фрізичної культури тощо. У наукових працях розкрито види і генезис мотивів, фрункції мотивів у детермінації життєдіяльності людини, особливості структури мотиваційної сфери особистості, мотиваційні основи діяльності. Суттєве значення серед вказаних досліджень займають питання формування мотивації до здорового способу життя, занять оздоровчою фрізичною культурою та здорового (в тому числі й оздоровчого) харчування як складової його частини $[1,4,7,9,14]$.

Мотивація (від лат. movere) - спонукання до дії; динамічний процес фрізіологічного та психологічного плану, що управляє поведінкою людини та визначає ії спрямованість, організованість, активність і стійкість; здатність людини діяльно задовольняти свої потреби [11]. У широкому розумінні, це почуття використовується в усіх галузях психології, соціології, які досліджують причини та механізми цілеспрямованої поведінки людини. На основі аналізу наукових джерел можна констатувати, що сьогодні в психолого-педагогічній літературі існує значна кількість визначень понять «мотив» та «мотивація» залежно від різних наукових поглядів на проблему мотивації $[4,13]$.

Проте важливо, що мотивація займає особливе місце в структурі компетентності людини (у тому числі й відносно здорового способу життя, оздоровчого харчування), оскільки належить як до фундаментальних сутностей, так і до здатностей, бо неодмінно включає в себе як зовнішні, так і внутрішні компоненти. Важливе місце належить і проблемі фрормування мотивації [4, 7, 14].

Згідно з рекомендаціями науково-методичної літератури, формування мотивації повинне спиратися на ту чи іншу психологічно підкреслену і системну модель цілісної мотивації, яка може бути сформована у вигляді програми (системи) формування мотивації. При цьому можуть бути використані різні форми для проведення формування мотивації: уроки-бесіди, театралізовані заняття, ігри тощо [7, 14]. 
Під час проведення уроків-бесід (як однієї 3 найпоширеніших форм фрормування мотивації дії) процес фоомування мотивації, насамперед, полягає в тому, що особа, яка проводить заняття, намагається під час цілеспрямованого впливу викликати ті чи інші зміни в мотиваційній сфрері. Щоб ці дії не мали випадкового і безсистемного характеру, потрібно орієнтувати процес на таку сукупність і збіг різних сторін мотивації, які повинні бути отримані. Необхідно орієнтувати їх не тільки на ізольовані особливості мотивації в окремому вияві, а й на перспективу, на завтрашній день розвитку, беручи до уваги особливості не тільки того чи іншого віку, а й враховуючи динаміку, вплив попереднього розвитку всієї мотивації навчання та окремих мотивів, які її спричиняють $[4,7,14]$.

Педагогічною наукою накопичено величезний досвід методів, які спрямовані на фоормування позитивних мотивів: емоційного стимулювання, формування відповідальності, навчальної дискусії, створення ситуації новизни, забезпечення успіху для досягнення поставленої мети, мотиваційного тренінгу (з використанням тренінгових вправ та ігор) тощо [4, 7]. Їх використання дає значні можливості формування мотивації до здорового способу життя та відповідно й оздоровчого харчування [4, 14].

Формування мотивації до занять фрітнесом, у тому числі й оздоровчої спрямованості, у дітей та підлітків займає особливе місце. Вказане, насамперед, обумовлено тим, що значне місце займають ігрові компоненти у фітнес-програмах для дітей та підлітків з метою їх кращого заохочення до занять фрітнесом та оздоровчою фрізичною культурою взагалі $[4,7,14]$.

Актуальність дослідження полягає в тому, що на практиці відмічаються випадки припинення занять фрітнесом або їх нерегулярного відвідування, неправильного харчування. Тренери, інструктори, менеджери фрітнес-клубів постійно стикаються з проблемою мотивації своїх клієнтів на тривалі заняття з фрітнес-програмами, недостатньою мотивацією до правильного харчування. Проведений аналіз показав, що до таких клієнтів передусім належать особи, які мають надмірну вагу (ожиріння), метаболічний синдром та шкідливі звички [10]. Тому з урахуванням зазначеного вище потрібно розробити систему оцінки та управління позитивною мотивацією до правильного харчування осіб, які займаються фрітнесом, а у разі потреби (ожиріння, метаболічний синдром тощо) до оздоровчого харчування.

Специфріка проведення занять 3 фітнесу як однієї зі складових фрізичного виховання полягає в тому, що усвідомлена інформація стає мотивованим спонуканням до фрормування такого способу життя (правильне харчування), яке сприятиме досягненню особистих та суспільних цілей [1].

Зв'язок роботи 3 науковими програмами. Роботу виконано згідно зі Зведеним планом НДР у соері фрізичної культури і спорту на 20102015 рр. за темою «Розробка системи оздоровчого харчування осіб, які займаються фрітнесом» (номер державної реєстрації 0111 U 00736).

Мета дослідження - розробка концептуальних підходів до формування позитивної мотивації в осіб, які займаються фрітнесом, до здорового способу життя, занять фізичною культурою та використання оздоровчого харчування.

Методи дослідження - теоретичний аналіз наукової та науково-методичної літератури: узагальнення, синтез, формалізація, абстрагування [3].

Результати дослідження та їх обговорення. Для оцінки ефективності формування мотивації, у тому числі і до занять фрізичною культурою, широко використовується анкетно-опитувальний метод (у різних модифікаціях) 3 рейтинговою (бальною) оцінкою результатів ефективності формування мотивації. Визначення виду мотивації, яка домінує (домінуюча мотивація), проводиться за результатами використання різних тестів оцінки ступеня мотивації тощо $[4,7,14]$.

При оцінці розвитку формування мотивації до досягнення мети необхідно враховувати можливість зниження рівня мотивації внаслідок зменшення $з$ часом дії стимулюючого чинника, що може становити серйозну проблему послаблення і навіть зникнення мотивації [14]. За даними останніх зарубіжних досліджень, близько 52$54 \%$ осіб, які займаються фітнесом, становлять жінки [18], в Росії вони становлять у середньому близько $60 \%$ [10]. В Німеччині найбільший відсоток осіб, які займаються, припадає на вік $25-34$ роки $(37,7 \%)$, потім молодше 25 років $(33,9 \%), 35-44$ роки $(15,3 \%)$ і старше 45 років $(13,1 \%)$ [18].

Основним фактором, що визначає мотивацію занять у фітнес-клубах, $\epsilon$ «фрітнес-здоров'я». Він становить 40,6\%. Наступним фактором $\epsilon$ «зовнішній вигляд» - 31,2 \%. Далі йдуть фрактори «психологічний» $(8,5 \%)$, «пізнавальний» $(7,4 \%)$, «соціальний» $(6,7 \%)$ і «прикладний» $(5,6 \%)$. Фактор «фрітнес-здоров'я» визначає такі мотиви: загальне поліпшення фрізичної підготовленості, поліпшення діяльності серцево-судинної системи (кардіотренованість), позитивний вплив на стан опорно-рухового апарату (поліпшення постави, зменшення болю в ділянці суглобів, спини тощо) [10]. 
Мотивація при проведенні занять із оздоровчого фрізичного виховання та оздоровчого фрітнесу повинна бути насамперед спрямована не на досягнення професійного результату, як це має місце, наприклад, у професійному спорті, а на здоров'я, здоровий спосіб життя, свідоме використання клієнтом засобів оздоровлення організму. Тобто оздоровчий мотив має домінувати над усіма іншими, що становлять загальний мотив (або мотиви) для занять з оздоровчого фітнесу $[7,16]$.

Формування мотивації до здорового способу життя, занять із оздоровчого фрізичного виховання проводять з використанням різних систем (програм) з відповідною оцінкою їх дієвості. Так, наприклад, було запропоновано програму (систему) фрормування потреби (мотивації) до занять фізичною культурою з використанням рейтингової системи оцінювання [7]. Також було розроблено систему поетапного формування мотивації до рухової діяльності в умовах освітньої установи [6]. Тобто фрормування мотивації повинне мати системний поетапний характер з рейтинговою оцінкою ефективності (дієвості) процесу фрормування мотивації.

Потрібно відмітити, що розглянуті системи формування мотивації до занять оздоровчим фізичним вихованням та фрітнесом за своїм призначенням стосуються тільки молоді, яка навчається у ВНЗ. Системи відповідно не охоплюють усі інші категорії. Однак розглянуті підходи до розробки програм формування мотивації можуть бути використані при створенні системи (програми) формування мотивації у клієнтів фрітнес-центрів до свідомого використання оздоровчого (функціонального) харчування.

При використанні систем (програм) фрормування мотивації до занять з оздоровчого фрізичного виховання реалізація мотивів відбувається за певною схемою: програма дії - уявлення, що треба робити для реалізації мотиву; оперативна готовність до дії - наявність здібностей, знань, вміння для виконання діяльності; наявність зворотного зв'язку - інформація стосовно ефективності дії [6].

При формуванні мотивації важливе місце займають дослідження мотиваційної спрямованості та визначення рівня домагань. Оцінюються такі компоненти мотиваційної структури особистості, як внутрішній мотив, що безпосередньо пов'язаний з процесом діяльності, пізнавальний мотив, що характеризує ставлення суб'єкта до результатів своєї роботи, мотив уникання, змагальний мотив, мотив зміни діяльності, мотив самоповаги, що характеризується у прагненні суб'єкта ставити перед собою в однотиповій повсякденній діяльності все складнішу і складнішу мету. Важливе значення мають вивчення та оцінка таких елементів мотиваційної структури, як ступінь вираження вольових зусиль, намічений рівень мобілізації сил, ініціативність, що надає можливість до проведення самооцінки рівня досягнутих результатів та інтелектуального потенціалу тощо. Як приклад проведення таких досліджень можна навести використання різних модифікованих фрорм (залежно від мети дослідження) опитувальника В. К. Горбачевського, в яких обробка результатів, які були отримані, проводиться за рейтинговою (бальною) системою (прямою або зворотною) [5].

Одним із найдієвіших мотивів фрормування стійкої мотивації $\epsilon$ позитивний стимул з позитивними емоціями. Це може бути, як приклад, тренінг фріксованих ролей за системою Д. Келлі. Для створення стимулу з позитивними емоціями для чоловіків проводиться рольова гра «чоловік 3 сильною чоловічою натурою», а для жінок «жінка з гарною зовнішністю» $[4,8,12,13,15]$.

Оцінка та формування позитивної мотивації до оздоровчого харчування в осіб, які займаються фрітнесом при надмірній вазі, потребують диференційованого підходу з урахуванням статі, оскільки у чоловіків превалює внутрішня позитивна мотивація, а у жінок - зовнішня позитивна мотивація [4, 8, 13, 17].

Для оцінки ступеня позитивної мотивації до оздоровчого харчування осіб, які займаються фітнесом, розроблено спеціальні анкети з бальною шкалою ступеня позитивної мотивації до правильного (оздоровчого) харчування $[2,4,14]$.

Важливе значення для формування позитивної мотивації має соціальний чинник, який $є$ різним для чоловіків та жінок. Так, для чоловіків у структурі соціального чинника на перше місце виходять такі фактори: досягнення більшої впевненості в собі та відчуття власної значущості, шанобливе ставлення оточуючих, можливість мати друзів. У жінок, навпаки, на першому місці можливість придбання друзів, потім шанобливе ставлення оточуючих і досягнення більшої впевненості в собі [10].

Важливо знати, що мотивація не $є$ постійною величиною, вона може змінюватися так само, як і загартовування організму в різних умовах середовища. Тому важливим $\epsilon$ створення позитивного середовища для підвищення рівня мотивації.

Висновки. За результатами проведеного аналізу літератури пропонуються такі концептуальні підходи до формування мотивації до здорового 
способу життя, занять фрізичною культурою та оздоровчого харчування у фрітнесі:

- фрормування мотивації до оздоровчого харчування у фрітнесі повинне проводитися системно 3 використанням відповідних програм (систем) поетапного фрормування мотивації, із застосуванням відповідних форм та видів формування мотивації, з використанням методів (тестів) рейтингової (бальної) оцінки дієвості фрормування мотивації;

- проведення фрормування позитивної мотивації до оздоровчого харчування має бути обов'язковим елементом оздоровчих фрітнес-програм;

- використання форм та методів фрормування мотивації до оздоровчого харчування повинно бути обумовлене індивідуальними особливостями (стан здоров'я) осіб, які займаються фрітнесом;

\section{Література}

1. БезВерхня Г. В. Мотивація до занять фрізичною культурою і спортом школярів 5-11-х класів: автореф. дис. на здобуття наук. ступеня канд. наук з фріз. виховання і спорту: спец. 24.00.02 «Фізична культура, фрізичне виховання різних груп населення» / Г. В. Безверхня. - Л., 2004. - 21 с.

2. Баин А. М. Современные иформационные технологии систем поддержки принятия решений: учеб. пособие / А. М. Баин. - М.: Форум, 2009. - 321 с.

3. Басков А. Я. Методология научного исследования / А. Я. Басков, Н. В. Туленков. - К.: МАУП, 2004. - 215 с.

4. Дипроуз Д. Мотивация / Д. Дипроуз. - М.: ЭКСМО, 2008. -256 c.

5. Дудло О. А. Гігієна в системі підготовки спеціалістів з фізичної реабілітації / О. А. Дуло, В. А. Товт, К. П. Мелега: навч. посіб. - Ужгород: Графіка, 2011. - 114 с.

6. Закурин Л. В. Формирование потребности к занятиям физической культурой у студентов технического вуза на основе рейтинговой системы оценивания: автореф. дис. на соискание учен. степени канд. наук по фриз. воспитанию и спорту: спец. 13.00.04 «Теория и методика фризического воспитания, спортивных тренировок, оздоровительной и адаптивной физической культуры» / Л. В. Закурин. - Шуя, 2005. - 17 c.

7. Захаріна $Є$. А. Формування мотивації до рухової активності у процесі фрізичного виховання студентів вищих навчальних закладів: автореф. дис. на здобуття наук. ступеня канд. наук з фріз. виховання і спорту: спец. 24.00.02 «Фізична культура, фрізичне виховання різних груп населення» / Є. А. Захаріна. - К., 2008. - 23 с.

8. Климчук B. A. Тренинг внутренней мотивации / В. А. Климчук. - СПб.: Речь, 2006. - 76 с.

9. Кібальник О. Я. Застосування фітнес-технології для підвищення рухової активності та фрізичної підготовленості підлітків: автореф. дис. на здобуття наук. ступеня канд. наук 3 фріз. виховання і спорту: спец. 24.00.02 «Фізична культура, фрізичне виховання різних груп населення» / О. Я. Кібальник. - Л., 2008. - 16 с.

10. Лисицька T. С. Соціологічний аналіз домінуючих мотивацій в осіб, які займаються у фрітнес-клубах / Т. С. Лисицька, С. І. Кувшіннікова // [Електронний ресурс]. 2012. - Режим доступу: http://crk-knteu.kiev.ua/ 75290-Sociologicheskiiy_analiz_dominiruyushih_motivaciiy_ zanimayushihsya_v_fitnes_klubah.html
- мотивація в оздоровчому фітнесі та відповідно в оздоровчому харчуванні має бути спрямована насамперед не на досягнення професійних результатів, як це має місце у професійному спорті, а на досягнення кращого стану здоров'я, на свідоме (активна позиція пацієнта) використання оздоровчих засобів, у тому числі й такого, як оздоровче харчування;

- при формуванні позитивної мотивації до занять фітнесом у дітей та підлітків необхідно використовувати ігрові компоненти фрітнеспрограм, а для жінок - мотивацію до краси тіла;

- при фооруванні позитивної мотивації до оздоровчого харчування слід враховувати статеві особливості чоловіків та жінок до внутрішньої та зовнішньої позитивної мотивації.

11. МотиВація. Матеріал з Вікіпедії - вільної енциклопедії [Електронний ресурс]. 2012. - Режим доступу: http://uk.wikipedia.org/wiki/ \%D0 \%9C \%D0 \%BE \%D1 $\% 82 \%$ D0 \%B8 \%D0 \%B2 \%D0 \%B0 \%D1 \%86 \%D1 \%96 $\% \mathrm{D} 1 \% 8 \mathrm{~F}$.

12. Ричи Ш. Управление мотивацией. 12 фактов мотивации / Ш. Ричи, П. Мартин. - М.: Юнити-Дана, 2009. - 400 с.

13. Скорнякова $A$. Медифит. Фитнес-технологии: пособие / А. Скорнякова, В. Горбунов. - М.: Медифит, 2009. - 200 c.

14. Соціально-просвітницький тренінг з формування мотивації до здорового способу життя та профілактики ВІЛ/ СНІДу / [С. В. Страшко, П. А. Животовська, М. Т. Хижняк та ін.]. - Сер.: Інноваційні технології та рефрорма змісту освіти. - К.: Освіта України, 2009. - 280 с.

15. Сидоренко E. Технология создания тренинга / Е. Сидоренко. - СПб.: Речь, 2008. - 329 с.

16. ТВеліна А. Мотивація та інтерес до заняття з фітнесу студентів спеціальності «фізична культура» / А. Твеліна, Г. Тарасова // Молода спорт. наука України. - 2008. Вип. 8. - Т. 4. - С. 218-221.

17. Цыганенко О. И. Концептуальные подходы к использованию оздоровительного (функционального) питания в фитнесе / О. И. Цыганенко, Н. А. Склярова, Л. Ф. Оксамытная, Н. Й. Ящур // Спорт. мед. - 2011. - № 1-2. С. $96-99$.

18. Boeckh-Behrens W. Gesundheitsorientiertes Fitnesstraining Dr. Loges + Co / W. Boeckh-Behrens, W. Buskies // GmbH, Winsen, 2002. - 350 s.

\section{Preferences}

1. Bezverhnjaja G. V. Motivatsija to employment of physical training and sports of schoolboys 5-11 classes: the dissertation author's abstract on competition of a scientific candidate's degree from physical training and sports: a speciality 13.00.04. «Physical training, physical training of different groups of the population» / G. V. Bezverhnjaja. - Lvov, 2004. - 21 p.

2. Bain A. M. Modern information technologists of systems of support of decision-making: the Manual / A. M. Bain. Moscow: the Forum, 2009. - $321 \mathrm{p}$.

3. Basques A. Ja. Methodolog's of scientific research / A. Ja. Basques, N.V. Tulenkov. - Kiev: Inter-regional academy of management of the personnel, 2004. $-215 \mathrm{p}$. 
4. Diprouz D. Motivatsija / D. Diprouz. - Moscow: ECSMO, 2008. - 256 p.

5. Dudlo O. A. Hygiene in system of preparation of experts from physical rehabilitation / O. A. Dulo, V. A. Tovt, K. P. Melega: the manual. - Uzhgorod: the Grafika, 2011. - 114 p.

6. Zakurin L. V. Formation of requirement to employment by physical training at students of a technical college on the basis of rating system evaluations: the author's abstract of the dissertation of the candidate of sciences: a speciality 13.00.04. "The theory and a technique of physical training, sports trainings, improving and adaptive physical training» / L. V. Zakurin. - Shuya, 2005. - 17 p.

7. Zaharina E. A. Formation of motivation to impellent activity in the course of physical training of students of higher educational institutions: the dissertation author's abstract on competition of a scientific candidate's degree from physical training and sports: a speciality 24.00.02 «Physical training, physical training of different groups of the population» / E. A. Zaharina. - Kiev, 2008. - 23 p.

8. Klimchuk V. A. Training of internal motivation / V. A. Klimchuk. - St.-Petersburg: Rech, 2006. - 76 p.

9. Kibalnik O. Ja. Applications of fitness technologies for increase of impellent activity and physical readiness of teenagers: the dissertation author's abstract on the competition of scientific degree candidate's from physical training and sports: a speciality 24.00.02 «Physical training, physical training of different groups of the population» / O. Ja. Kibalnik. - Lvov, 2008. - 16 p.

10. Lisitsky T. S. Sociological the analysis of dominating motivations at persons who are engaged in fitness clubs / T. S. Lisitsky [the Electronic resource]. 2012. - an access Mode: http://crk-knteu.kiev.ua/75290-Sociologicheskiiy_ analiz dominiruyushih motivaciiy zanimayushihsya $v$ fitnes klubah.html

11. Motivation. A material with Wikipedia - the free encyclopaedia [the Electronic resource]. 2012. - an access Mode: http://uk.wikipedia.org/wiki / \% D0 \%9C \%D0 \%BE \%D1 \%82 \%D0 \%B8 \%D0 \%B2 \%D0 \%B0 \%D1 $\% 86 \% \mathrm{D} 1 \% 96 \% \mathrm{D} 1 \% 8 \mathrm{~F}$

12. Richi S. Management motivation. 12 facts of motivation / S. Richi, P. Martin. - Moscow: Juniti-Dana, 2009. - 400 p.

13. Skornjakova A. Medifit. Fitness - technologies: the grant / A. Skornjakova, V. Gorbunov. - Moscow: Medifit, 2009. - 200 p.

14. Socially elucidative training from motivation formation to a healthy way of life and human immunodeficiency virus preventive maintenance / syndrome of the purchased immune deficit [S. V. Strashko, P. A. Zhivotovska, M. T. Hizhnjak and others]. - Series: Innovative technologists and reforming of the maintenance of formation - Kiev: Osvita Ukraine, 2009. - 280 p.

15. Sidorenko E. Tehnologija of training creation / E. Sidorenko. - SPb: Rech, 2008. - 329 p.

16. Tvelina $A$. Motivatsija and interest to employment from fitness of students of a speciality «physical training» / A. Tvelina, G. Tarasova // the Young sports science of Ukraine. - 2008. - Series 8. - Volume 4. - P. 218-221.

17. Tsyganenko O. I. Conceptual approaches to use of an improving (functional) food in fitness / O. I. Tsyganenko, N. A. Sklyarov, L. F. Oksamytnaja, N. J. Jashchur // Is sports medicine. - 2011. - N 1-2. - P. 96-99.

18. Boeckh-Behrens $W$. The fitness training of doctor Logesa focused on health + To / W. Boeckh-Behrens, W. Buskies // Hamburg, Winsen, 2002. - 350 p. 